\title{
Deuteronomy 15:1-11 and its socio-economic blueprints for community living
}

\begin{abstract}
Author:
Blessing O. Boloje ${ }^{1}$ (1)

Affiliation:

${ }^{1}$ Department of Old

Testament Studies, Faculty of Theology and Religion, University of Pretoria, South Africa

\section{Research Project} Registration:

Project Leader: A. Groenewald (1)

Project Number: 02428024

\section{Description:}

Dr Boloje is participating in the research project,

'Exegesis and the Theology of Isaiah', directed by Prof. Dr Alphonso Groenewald, Department of Old Testament Studies, Faculty of Theology and Religion, University of Pretoria.
\end{abstract}

Corresponding author: Blessing Boloje, pstbobson@yahoo.co.uk

Dates:

Received: 08 June 2018 Accepted: 25 July 2018 Published: 25 Oct. 2018

How to cite this article: Boloje, B.O., 2018, 'Deuteronomy 15:1-11 and its socio-economic blueprints for community living', HTS Teologiese Studies/ Theological Studies 74(1), a5147. https://doi.org/ 10.4102/hts.v74i1.5147

\section{Copyright:}

(C) 2018. The Authors. Licensee: AOSIS. This work is licensed under the Creative Commons Attribution License.

Read online:

Scan this QR
code with your
smart phone or
mobile device
to read online.

Biblical criticism regards biblical books as fundamental texts expressing and embodying the core of faith and practice of a believing community. Thus, in line with canonical criticism, this article assumes the Book of Deuteronomy as a basic text, cherished and believed by those who practice the Jewish and Christian faiths. Primarily, the article analyses the text of Deuteronomy 15:1-11 against the background of its social vision for community living in ancient Israel. The potential significance of this humanitarian and/or brotherly ethics and its associated benefits are the secondary concerns of the article. The article, however, does not preclude reflection on scholarly discussions regarding Deuteronomy's compositional history, though with limited focus. The article holds that a practical understanding and appropriation of Deuteronomy's radical humanitarian vision will not only help in raising a healthy community which functions as an alternative to poverty but also reinvigorate commitment to a mission of social responsibility for God's people living in covenant and/or faith communities.

\section{Introduction}

Biblical criticism regards biblical books as fundamental texts expressing and embodying the core of faith and practice of a believing community (Hayes \& Holladay 1982:122). Thus, in line with canonical criticism, ${ }^{1}$ this article assumes the Book of Deuteronomy as a basic text, cherished and trusted by those who practice the Jewish and Christian faiths. As one of the widespread and allembracing theological masterpieces of Israel's literary texts, the Book of Deuteronomy reflects concerns on key theological ideas that serve as basic societal fabrics through which Israel's relationship with God is uncovered and experienced. It articulates a theology of Yahweh's people "par excellence by systematising the theory for the social centre of a "civilisation of love"' (Friedl 2016:182). The book's impact on Jewish identity and nationality is without dispute (Labahn 2007:82). It is not only used or quoted in ancient Jewish literary texts but also most frequently cited, mentioned or quoted in Old Testament texts (Lim 2007:6). Significant allusions to Deuteronomy have been observed with reference to the correspondence in the speeches of Peter, Stephen and Paul in Acts (Rusam 2007:65-75). These allusions, as Lohfink (1996:3) suggests, point to Israel and then successive eschatological and messianic Christian communities. Its eschatological significance is reflected in the ecclesiology of the early Christian community in Acts (Friedl 2016:176f.; Mitchell 1992:256). Scheffler (2013) examines the theme of poverty in the 'Pentateuch-narrative' or 'novel' and highlights its continuing contemporary challenge. His contemporary appropriation includes:

... the ancient context $(s)$ in which the biblical text $(s)$ functioned and ... the present-day context in which an
attempt is made to responsibly appropriate these texts and the historical constructions we made regarding
them. (p. 1)

This article recognises the difficulty of an actual theological application of Deuteronomy's social vision in a particular religious, political, social, economic and cultural context. Being aware of the diversity of cultural differences and historical circumstances and consciousness as well as the difficulty of translating this humanitarian vision into down-to-earth reality, the moral principles of the vision allow the writer to overtly generalise the socio-economic implications, especially for believing communities. The connection between ancient Israel's socio-economic challenges and

1.Canonical criticism operates on several principles. Childs' canonical critical principles include the following: it gives interpeters room for theological reflection on the biblical text as it is received and shaped. It holds that the final form of the text has a long history of development. It approaches biblical theology as a combination of constructive and descriptive elements. It allows for flexibility, and it acknowledges the existence of the text within a community of faith. It accepts the canon as normative and authoritative in the practice of Christian faith and allows the theologian or interpreter to acknowledge the illuminating role of the Holy Spirit in the understanding and application of the text (Childs 1985:11-15).

Note: This article is based on the research conducted and presented by the author during the International ProPent Conference held at the University of Pretoria (02-04 September 2017) on 'The Pentateuch and its Reception (in other parts of the Bible or Early Judaism or Christianity)'. 
contemporary socio-economic reality makes Deuteronomy's humanitarian vision appealing. As observed and also experienced, individuals, families, communities and national economies are going through difficult times of various socioeconomic realities. In Africa, for example, it is noted that the increase of poverty is accentuated by the rise of corruption (Deng 1998:141-146). Although there is no consensus definition of poverty, ${ }^{2}$ Townsend (2006) notes:

'... people can be said to be in poverty when they are deprived of in-come and other resources needed to obtain the conditions of life - the diets, material goods, amenities, standards and services - that enable them to play the roles, meet the obligations and participate in the relationships and customs of their society. (p. 5)

Although poverty could be relative as well as absolute (Burkey 1993:3-4), corruption assumes various shades: soliciting for or negotiating for direct or indirect giving or receiving of something which is of value so as to dishonestly and inappropriately influence the intentions of someone (Ndiyo 2010:175).

In the midst of the rising and alarming rate of poverty and corruption, unemployment and other socio-economic pressures, there is exploitation to the degree that many less privileged individuals are held as economic hostages. Primarily, this article seeks to analyse the text of Deuteronomy 15:1-11 against the background of its social vision for community living in ancient Israel. This analysis, however, does not preclude reflection on scholarly discussions regarding Deuteronomy's compositional history, though with limited focus as a background. It maintains that a practical understanding and appropriation of Deuteronomy's radical humanitarian vision will not only help in raising a healthy community which functions as an alternative to poverty but also reinvigorate commitment to a mission of social responsibility for God's people living in covenant and/ or faith communities (see Davidson, Mock \& Johnson 1997: 247f.; Gray 2008:221). Secondly, the article undertakes a theological examination of the social responsibility of Deuteronomy's humanitarian vision as a model for covenant community living and as a viable alternative to poverty.

\section{Compositional history of Deuteronomy}

Scholarly discussions regarding Deuteronomy's compositional history are varied (see Levinson 1997:98-143; Mc-Conville 2002:21-40; Pakkala 2009:388-401), and it is relatively difficult to step deeply into the frontier of the extensive debates in this article. Thus, limited preliminary remarks are made in this section. The purpose is to highlight the literary development of the social directives and the difficulty involved in the interpretation and appropriation of its social vision. As noted:

2.Scheffler (2013) examines the different Hebrew terms for poverty in the Torah and creates a distinction between that: “. the varions expressions regarding povety origin contingently in their ancient contemporary contexts but that they can also be critically appropriated in present-day contemporary contexts - for which a great need exists' (p. 2)

\begin{abstract}
... the question of dating ... has too often taken priority over the question of purpose, and, having been widely regarded as settled, has rather predetermined the more basic questions of nature and purpose. (Davies 2014:27)
\end{abstract}

It is argued that the final version of the text of Deuteronomy is the result of a redactional process (Miller 1990:147). From a geographical point of view, the scholarly bent that imagines a Judean or Judahite setting has given rise to the belief that the Book of Deuteronomy or some aspects of it originated during Josiah's reign (639-609 BCE), as reflected in 2 Kings 22-23 (see Le Roux 2005:15-18; Levin 2014:49; Otto 1994:180-186). Nelson (2002:8) notes that Deuteronomy was written, 'As a covert undertaking by dissident Jerusalem scribal circles during the reign of Manasseh and the minority of Josiah,' in partnership with 'aristocratic families, elements of the priesthood, and those schooled in wisdom'.

In light of the language similarities between some aspects of Deuteronomy and Proverbs, Weinfeld (1991:56-57) associates the authors of the Book of Deuteronomy to scribes who were experts in the traditional institution of wisdom in the ancient Near East and suggests that it was written after Proverbs. While there is correspondence between the laws of Deuteronomy (12-26) and ancient Akkadian traditions, the laws of Deuteronomy regulate particularly the social aspects of Israel's life in contrast to vassal treaties (Davies 2014:30). It is striking to note that the social regulations in Deuteronomy appear to indicate a well-ordered socio-economic and religious society. Such a kind of community has more of a collective identity and relationship with the Judaism of the Second Temple period and less with the Judaism during the monarchic era (Levin 2014:50). There is also a growing interest among scholars in situating Deuteronomy's origin in a postmonarchic era (Davies 2005:65ff.; Albertz 2005:27-46). These geographical tendencies, however, have not diminished the age-long and established scholarly tradition of Deuteronomy's origin during the Israelite monarchy (Fohrer 1968:174; von Rad 1953:68; Wright 1953:311-330).

The book, no doubt, presents challenges of interpretation. One of the challenges in the interpretation of Deuteronomy is what Levin (2014) refers to as its 'utopian character':

It is 'u-topian' in the sense that its location in history is not unequivocally clear. The biblical setting is fictitious, and this is not by chance. It is supposed to be Moses' discourse on the last day of his life, immediately before the conquest of West Jordan. (p. 49)

Although Deuteronomy's utopian social vision of an ideal Jewish covenant community is difficult to establish even within the border of Israel (Collins 2000:58), Deuteronomy promulgates its vision and laws as an exhortation with conviction that such a model society which appears to be difficult to achieve can be a lived reality if Israel adopts appropriate behaviour, namely Torah compliance (Collins 2000:53). According to Davies (2014): 
Deuteronomy defines a novel conception of the manner of the relationship between 'Israel' and its 'tribes' $(1: 13,15 ; 5: 23 ; 12: 5,14$; $16: 18 ; 18: 5$ etc.) on the one hand and its deity on the other. This relationship is articulated in terms of a 'covenant' (ברית běrit occurs twenty-seven times in the book) between the deity and the people, and encompasses nearly all aspects of social and domestic life. (pp. 27-28)

The book gives a voice to a humanitarian vision for viable community living in Israel. This is clearly stated in Weinfeld's (1961) argument, namely:

... the primary aim of the Deuteronomic author is the instruction of the people in humanism, and in furtherance of this goal he adapts the various literary traditions which were at his disposal. (p. 242)

Deuteronomy's humanist regulations according to Weinfeld (1961:241) are: laws calling attention to the value of human life and human dignity (Dt 21:10-14, 22-23; 22:8; 23:16; 25:1-3); laws regarding human, interpersonal and social relations, wherein one finds appeals for helping foreigners, orphans, widows and the poor, as well as encouraging a positive attitude toward those at the margins of society (Dt 15; etc.), regulation of property rights (Dt 23:25) and warnings regarding the treatment of a hated wife and her son (Dt 21:15-16); and Laws emphasising the humane treatment of animals (Dt 22:6-7). The following section analyses the text of Deuteronomy 15:1-11 against the background of its social vision for community in ancient Israel and thus a model platform for contemporary faith community and societal reflection.

\section{Deuteronomy 15:1-11: Structure and analysis}

Deuteronomy 15 is considered by scholars as part of Deuteronomic 'utopia' (Lohfink 1996:2-19; Uhlenbruch 2015: 18-20). However, other scholars have considered the regulation as an ideal (Christensen 1991:313; McConville 2002:259). It is a classic text that deals with the eradication of poverty and the avoidance of poverty prevention, not only in Deuteronomy but especially within the Pentateuch as a whole (Oosthuizen 1997:64; Scheffler 2013:6). Scheffler (2013) remarks that:

The Deuteronomic Code (Dt 12-26, especially 15:1-18) ... covers (amongst others) economic problems brought about by a primitive capitalist monetary economy which started to develop ... In this context, where money could be borrowed to compensate for economic losses, poverty became a burning problem. Judean intellectuals (who were responsible for the text) experienced an unsatisfactory reality and visualised a better one. (p. 6)

A careful reading of the text of Deuteronomy 15 reveals two intimately and inseparably connected social regulations: remission (Dt 15:1-6) and lending (Dt 15:7-11). Below is the text and structure ${ }^{3}$ of the literary development of the social regulations:

3.Levin $(2014: 52-54)$ presents an outline of the sequence of Deuteronomy 15:1-11 quite differently. However, the highlighted sections of the translation of the text in
this article reflect his critical structural analysis. In his translations of the old stipulations, that is, 'the Vorlage of the Deuteronomic editor', are printed in bold stipulations, that is, 'the Vorlage of the Deuteronomic editor', are printed in bold
type, and the text of the Deuteronomic editor in italics. The history edition as well as the covenant edition and finally the edition that stresses Israel's election ove against the other nations are printed in normal types and marked by indentation. The brotherhood edition is underlined; the edition regarding the poor is given in plain font (Levin 2014:52).

\author{
The Prescriptions (VV. 1-6) \\ Declaration of the law (15:1)

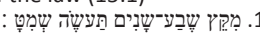 \\ 1. At the end of every seven years \\ you shall grant a remission (of debts, \\ cf. Dt 31:10)
}

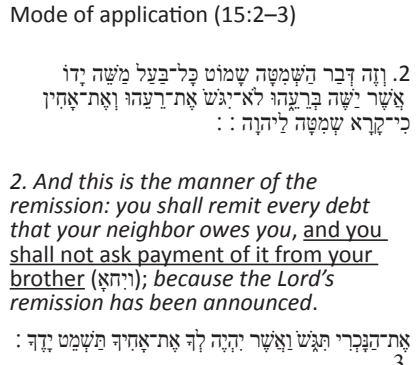

4. From an alien (foreigner, stranger) (ה) vou mav exact it (press for repayment), but whatever your brother (אָ) owes you, you hand shall remit (pardon) his debt.

Probability of application (15:4-6)

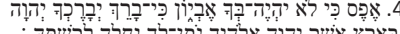

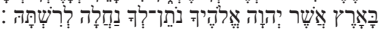

Because there shall be no poor (דוֹיוֹיבֶ) person among you. For the LORD your God will bless you in the land which LORD your God gives you for an inheritance to possess.

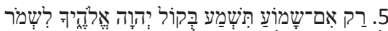

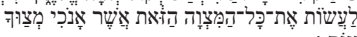
הַי

5. If you should listen to the voice of the LORD your God, being careful enough to observe all this commandment which I command you today.

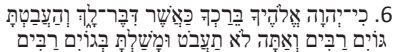

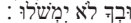

6. For the LORD your God has blessed you, as he promised you, and you shall lend to many nations, but you shall not borrow; and you shall rule over many nations, but they shall not rule over you.

\section{The declaration of the law (Dt 15:1)}

The day-to-day life of Israel in the land of promise is regulated in relation to debts and slavery. These ideas are understood as ways in which the stronger might help the weaker in the community. Deuteronomy 15 falls within a context of the Sabbath year of Exodus 23:10-17 and Leviticus 23, 25, with the most interesting features being that land and people could be bought and sold and be released at certain times. Interestingly, the law in Exodus 23 establishes a release of the land with a regulation that landowners are prohibited from cultivating in the seventh year. The reason for the accommodation of 'resting' the land is that those who have fallen into hard times (the poor and needy) may garner leftover food crops and also for the benefit of wild animals 
(Ex 23:11). In the course of the year of release, food crops and harvest of the land are treated as exclusively belonging to the landowner but become corporate and shared belongings. In the same manner, Leviticus 25 promulgates a Sabbath rest for the seventh year. In its decree, the land is to remain uncultivated. Deuteronomy 15, however, extends a special interest of the laws of release in Exodus and Leviticus by establishing a framework for the support of the landless poor and needy. Vogt (2008) notes:

Significantly, care of the landless and poor is established in Deuteronomy as one of the most important measures of the effectiveness of the people of Israel in living out loyalty to Yahweh and, therefore, being the people of God. Thus, social justice is an important expression of relationship with Yahweh, and as such has at its core a profound theological and spiritual foundation, rather than a secularized humanitarianism. (p. 35)

\section{Mode of application (Dt 15:2-3)}

The Sabbath year was a year of relief and also a year of great distress; the release alleviates the burden of debt for debtors and slaves through compassion and forgiveness but places an encumbrance on the wealth of the creditor. Sabbath's ethical requirements are that debtors and slaves be set free and that the Israelites were not only to help the poor but to refrain from what would be hardship and oppression for them. As observed by Vogt (2008):

Deuteronomy 15 calls for the release of debts in the seventh year, and also for the release of slaves, who probably entered servitude because of indebtedness. Although it is debated whether this release originally was intended to be a total cancellation of the debt or referred to suspension of demands for payment during the seventh year, there is no doubt that later Jewish tradition understood this to be a complete cancellation of the debt. (p. 37)

Although a number of scholars have supported the view of complete cancellation of debt (see Christensen 2001:310; Dummelow 1937:129; Wright 1996:188), Craigie (1976:236237) and McConville (2002:258-260) hold that the law refers to suspension of debts rather than cancellation of indebtedness. This remission in my estimation and in all probability was applicable to generous loans that were without interest. In this regard, the remission would be considered to be absolute, thus amounting to a donation.

The idea of brotherhood in Israel is nowhere else stronger than in verses $2-3$. These verses are considered to be redactional 'Deuteronomic reworking' of the directives (Levin 2014:55). The subjects requiring help are described in

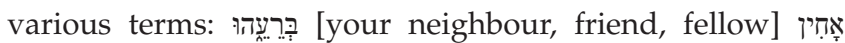
[brother, blood relative, fellow tribesman] (15:2). However, dealings with fellow Israelites are on a different footing from dealing with foreigners (15:3 cf. 14:21). A stranger (נָכְְרי) from another nation was distinguished from those who lived among them and had a claim to benevolence, but had no right to remission and privileges. This gives protection to an Israelite and displays no hatred or injustice to a foreigner. Neighbours (רֵַ) must be released. Fellow Israelites (אָחזיף) were members of one society and regarded as a 'common brotherhood', a type of 'household faith', enjoying equal rights and privileges. These neighbours are described as debtors. The poor borrowed neither for trade nor extravagance, but for survival. He could not pay without reducing himself to poverty. Thus, kindness must be shown by the lender and gratitude by the borrower (McConville 1998:214).

The regulations build on the idea of Israel as an ethical community, showing within itself the standards of Yahweh (McConville 1998:214). Debts were to be cancelled in the seventh year of a seven-year circle because loans were to be made without interest (Dt 23:19-20; Ex 22:25). ${ }^{4}$ Although the tradition of money lending or usury and all its associated problems is well recognised in ancient Near Eastern society, the Old Testament regulation permitted granting of loans to foreigners but disallowed charging interest on loans granted to fellow Israelites (Lv 25:35-38; Dt 16:19-20). Loans were clearly an act of assistance to those who had fallen on hard times (as a result, probably, of a poor harvest) rather than a means of enriching the lender (McConville 1998:214). The motive for lending rested essentially in the nature of Israel's relationship with Yahweh. As people in covenant, they must live out its brotherhood and knowledge if they hold their land not by reason of strength (Dt 8:17) but as Yahweh's gift. Throughout the history of Israel, it is clear that the relationship between God and his people is intricately linked to the land, which has been given to them:

Israel's involvement is always with the land and with Yahweh, never only with Yahweh as though to live only in intense obedience, never only with land as though simply to possess and manage. (Brueggemann 1978:3)

This intricate association is most obvious in the deliberate use of the language of 'inheritance' (ניחדָלָה) in connection with Yahweh's gift of land to Israel. ${ }^{5}$

\section{Probability of application (Deuteronomy 15:4-6)}

The consequence of rightful application of the law is that

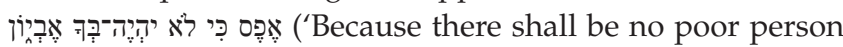
among you' v. 4), which is actually a command. Regarding

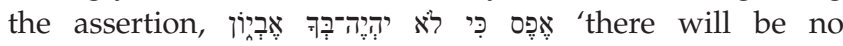

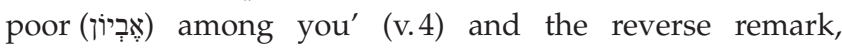

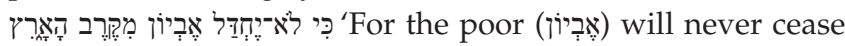
out of the land' (v. 11), Levin (2014:59) notes:

In the first case, the reality of poor and rich would be contrasted with the goal of a society without marginal groups; in the second case, the social utopia would be subjected subsequently to the test of reality. But in actual fact, it is a question neither of the one nor the other. It is rather that the author of v. 11a is resisting the notion that the commandment threatens the existence of the

4.Whilst this is debatable, particularly with respect to the nature, circumstances and scope (Buch 2005:13-22), the underlying principle is that of concern for mercy and justice required of the lender (Kessler 2013:401).

5.The land owes its existence to him, and he creates its inhabitants, continually supervising or monitoring their behaviour. He allocates land to people $(\mathrm{Gn} 2: 8$; 15-16-21: Dt 2:5, 9 and 19). Conversely, he removes people from the land when they do not behave in a worthy manner (Gn 3:23-24, 11:8; 15:16) (McKeown they do not
2003:487). 
poor. For him, poverty is not a condition that ought to be overcome; it is the mark of a religious group characterized by its special closeness to God. To say 'the poor will never cease out of the land' is as much as to say 'the poor (עָנָנוּים) will inherit the land'. (Ps 37:11; cf. Mt 5:5)

If 'Israel' truly embodies the standards of Yahweh within itself as an ethical community, though there may be poverty 'in the land', it will not be the case for 'Israel' (Levin 2014:58). In this regard, there is no contradiction in Deuteronomy 15:4 and 11; but these two verses should be regarded as two halves of one radical humanitarian vision. Ideally, Israel as a community of faithful and loyal worshippers of Yahweh should not have the poor in her midst as everyone is welcomed, incorporated and cared for. Human beings, however, are incompetent regarding the creation and maintenance of such an impeccable selfishness, and as such, the poor will always be there in the land. Deuteronomy 15 attempts to reduce, if not eliminate, 'the impact of the failure of the people to live selflessly through the law of release of slaves in the seventh year' (Vogt 2008:41). The fulfilment of this command rested in Israel's responsibility for justice and thus continued experience of Yahweh's blessing (vv. 4-6) (McConville 1998:214). As declared and explained by Moses, the gracious bestowal and enjoyment thereof of Yahweh's blessings is contingent upon Israel's radical and wholehearted compliance to Yahweh's command in all of its entirety: If you should listen to the voice of the LORD your God

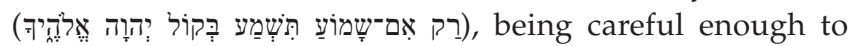

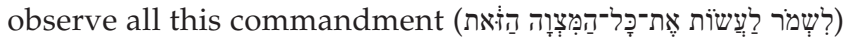

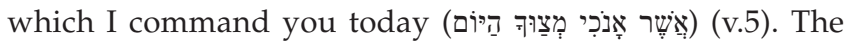
fact that the poor will certainly be found among covenant

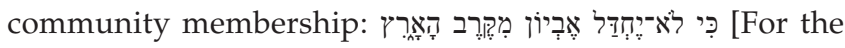
poor will not cease to be in the land' v. 11a] expands the vision to include measures of dealing with the situation.

\section{Application in severe cases (Dt 15:7-11)}

The regulation includes an exhortation to unconditional generosity which is developed in verses $7-11 b$. In these verses (application of the law in severe cases), Moses admonishes them not to be hard-hearted and oppressive, but to cherish a spirit of charity and with liberality. Here one finds safeguards against oppression, and checks upon selfishness and rapacity, firstly by providential interposition (it is the Lord's release which no authority could prevent) and secondly by enforcement of

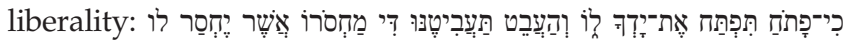
'For you shall freely open hand to him. Generously lend to him what is sufficient to meet his need' (v. 8). The claims of the poor upon the rich - claims of help in their poverty and claims of sympathy in distress - were to be generously and gladly met. The evasion of this duty was a sinful violation of the spirit of the law:

Pay attention to yourselves least there be a worthless thought in your heart, and you say, the seventh year, the year of remission of debts is near, and your eye be hostile toward your poor brother

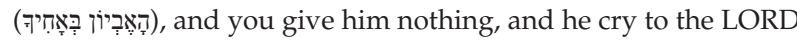
concerning you, and it will be sin (חָ) in you. (v. 9)
Following the basic principle of the Torah, Israel is unique to other nations. Here the regulation envisages and situates Yahweh at all of Israel's boundaries, such that he is open and attentive to the cries of the needy. The cries of the needy upon Yahweh within the context of indebtedness constitute sin (טị) on the part of those who have failed to combat poverty (Lohfink 1996:16). Thirdly, unconditional commitment and cultivation of kindly feelings is stressed. Special consideration must be given to the poor, because oppression is an offence to God (v. 9), their cry is heard by God (v. 9) and liberality to the poor will be rewarded: You

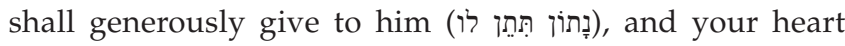

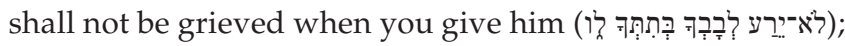
because for this reason, the LORD your God will bless you

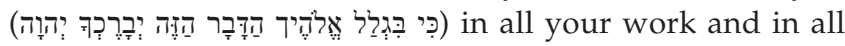

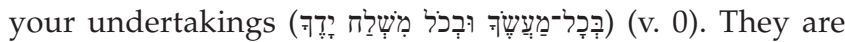
not only to bestow the gift, but cherish right feeling. They are to think, feel and act as God does, who is pitiful and of tender mercy. Here, considerate self-sacrifice is required of the lender. However, no limit is required of the generosity of the giver (cf. Rm 12:8; 2 Cor 9:7). It is an open-ended commitment to other people (McConville 1998:215).

\section{Socio-economic implications and conclusion}

One of the essential aspects of Israel's distinctiveness as a nation is her relationship with Yahweh, which has implications for life in society. The correspondence between faith and life in the community of humanity is what stimulates Routledge (2008) to remark:

Faith must be worked out in practice in individual and national life; it involves relationship with God and so may not be reduced to a mechanistic system of appeasement or seeking divine favour through ritual. True faith in God must be accompanied by practical commitment that shows itself in right living. (pp. 238-239)

The strength of the analysis of Deuteronomy's humanitarian vision $(15: 1-11)$ is the unfolding theological character of the text. Underlying this analysis are three primary features of this regulation: Yahweh as the key actor, the Israelite community and community members as beneficiaries of compassionate deeds, and the wisdom or truth that captures the hearers' or readers' attention toward appropriate action. Deuteronomy 15:1-11 seeks to avoid the institutionalisation of perpetual poor disadvantaged individuals through its laws of release. The vision which is expected to be an ideal or a lived reality in a covenant community of Yahweh's people invites community members to a recognition and appreciation of the obvious reality of members' social needs and practical social responsibility. It presumes that a right relationship with Yahweh will transform society. Society is separated into distinct classes, yet bound together into one harmonious entity. If rich and poor would each do their duty in their station, they would reciprocally become a blessing and support to the other. Deuteronomy's radical humanitarian vision functions both as a future hope and also as an ethical demand in the present (Wright 2004:206). Economically, the 
vision existed to protect a form of land tenure system based on an equitable and widespread distribution of the land, and to prevent the accumulation of ownership in the hands of a wealthy few. Thus, the moral principles of the vision are universalisable on the basis of the moral consistency of God (Wright 2004:207).

At a social level, the regulation expresses and embodies pragmatic concern for family cohesion. The morality of a family unit is considerably worthless if families were being dispossessed and split up by socio-economic forces that made them powerless and helpless. Deuteronomy's radical humanitarian vision is targeted at restoring the social dignity of families and their active participation in community through the restoration and sustenance of their economic capability. One must acknowledge that debt is a considerable factor for social disturbance and degeneration and can become a breeding ground for several other social vices, including poverty, squalor, crime and violence. The practice of Deuteronomy's radical socio-economic vision will help reduce, if not eliminate, relentless and endless social consequences of debts. The development of a brotherhood ethic which lacks sufficient parallel in the Old Testament indicates an essential and far-reaching social regulation aimed at creating and maintaining a classless tribal society and eradicating inequalities. This social humanitarian vision which is counter-society in its framework involves not only meeting material needs of people in a covenant community but also creating opportunities for active participation of community members in all of Israel's moments of joy, particularly on festive occasions.

Theologically, the vision is based upon sacred key affirmations of Israel's faith. The driving force of this humanitarian

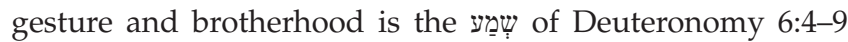
that speaks most pointedly about Yahweh's solidarity and Israel's responsibility of fidelity in community. It celebrates the sovereignty of God over time and nature, and obedience to it would require submission to that sovereignty. Accordingly, Israel's covenant fidelity generates a viable and healthy social situation with a unique brotherhood model (Friedl 2016:184). Thus, the biblical perspective of the vision is an acknowledgement that no one can live without the security, dignity and well-being that are associated with the freedom and rights of the other. Faith in Yahweh in the Bible moreover concerns a commitment to the just sharing of land, its produce and its guarantees.

On the one side of this vision is the negative implication in which one finds the significant critique of the massive enterprise of colonialism in contemporary society and a world in which imperial powers have occupied and repossessed lands that are not theirs. On the positive side, this humanitarian and/or brotherly ethics and its associated benefits are a generic affirmation of emancipatory movements whereby disadvantaged individuals receive back their privileges that have hitherto been denied them. To apply this vision as an alternative model for a healthy, viable community requires that people obey Yahweh's sovereignty, trust his providence, know and understand the story of his redeeming actions, experience personally the atonement he provides, practice Yahweh's justice and put their hope in Yahweh's promise. The whole of this practical, radical model vision embraces the church's evangelistic mission, its personal and social ethics and hope (Wright 2004:209). On the whole, the connection between God and his people in the land (a major fabric upon which Israel's relationship with God rests) makes the biblical tradition continuously revolutionary and radical in its social, economic and theological functions.

The overall aim of Deuteronomy's humanitarian vision is the eradication of poverty in all of its shades. This distinctive humanitarian vision, though nationalistic in orientation (that is within the boundaries of Israelites' own community), can find contemporary theological categories and appropriation of perspectives within the context of extreme socio-economic contradictions, especially regarding poverty in (various nationalities in Africa and) the world. Poverty can be alleviated, if not completely eradicated, when the feelings, desires and voice of the poor and enslaved arouse our empathy and compassion, when we view humanity as a global family and are driven by a deep sense of identification and compassion to work for change despite challenges (Scheffler 2013:10). The vision grants insight into the distinctive social responsibility of the Christian Church that is commissioned by God (Mcllroy 2011:189-190; Sacks 2005:135) not only to embody his ethical requirements for justice and righteousness within herself but also to humbly enter into other people's worlds (of sorrow and suffering, social isolation, struggles for justice against oppressive powers, economic poverty and exploitation) and identify their socioeconomic realities. An appropriation of this social vision, at least within an ecclesia community, will become a viable channel for alleviating, if not eradicating, poverty in larger human society.

\section{Acknowledgements Competing interests}

The author declares that he has no financial or personal relationships that may have inappropriately influenced him in writing this article.

\section{References}

Albertz, R., 2005, 'Why a reform like Josiah's must have happened', in L. L. Grabbe (ed.), Good kings and bad kings: The Kingdom of Judah in the seventh century, pp. 27-46, ESHM 5/LHBOTS 393, T\&T Clark, London.

Brueggemann, W., 1978, The land: Place as gift, promise and challenge in biblical faith, Fortress Press, Philadelphia, PA.

Buch, J., 2005, 'Neshekh and Tarbit: Usury from Bible to modern finance', Jewish Bible Quarterly 33(1), 13-22.

Burkey, S., 1993, People first: A guide to self-reliant, participatory rural development, Zed Books, London.

Childs, S.B., 1985, Old Testament theology in a canonical context, Fortress, Philadelphia, PA.

Christensen, D.L., 1991, Deuteronomy 1-21, Word Biblical Commentary, Word Books, Dallas.

Christensen, D.L., 2001, Deuteronomy 1:1-21:9, rev. edn., Thomas Nelson Publishers, Nashville, TN. 
Collins, J.J., 2000, 'Models of utopia in the Biblical tradition', in S.M. Olyan \& R.C. Culley (eds.), A wise and discerning mind: Essays in honor of Burke O. Long, pp. 51-67, (eds.), A wise and discerning mind: $\mathrm{Es}$
Brown Judaic Studies, Providence, RI.

Craigie, P.C., 1976, Deuteronomy, NICOT, Eerdmans, Grand Rapids, MI.

Davidson, J.D., Mock, A.K. \& Johnson, L., 1997, 'Through the eye of a needle: Socia ministry in affluent churches', Review of Religious Research 38(3), 247-262. https://doi.org/10.2307/3512086

Davies, P.R., 2005, 'Josiah and the Law Book', in L.L. Grabbe (ed.), Good kings and bad kings: The kingdom of Judah in the seventh century, pp. 65-77, ESHM 5/LHBOTS 393, T\&T Clark, London.

Davies, P.R., 2014, 'The authority of Deuteronomy', in D.V. Edelman (ed.), Deuteronomy-Kings as emerging authoritative books: A conversation, pp. 27-47, Ancient Near East Monographs 6, Society of Biblical Literature, Atlanta, GA.

Deng, L.A., 1998, Rethinking African development: Towards a framework for social integration and ecological harmony, Africa World Press, Asmara.

Dummelow, J.R., 1937, Commentary on the Holy Bible, The Macmillan Company, New York.

Fohrer, G., 1968, Introduction to the Old Testament, transl. D. Green, Abingdon, Nashville, TN.

Friedl, A., 2016, 'The reception of the Deuteronomic social law in the primitive church of Jerusalem according to the book of Acts', Acta Theologica Supplementum 23, 176-200. https://doi.org/10.4314/actat.v23i1s.9

Gray, D., 2008, 'Beyond orthodoxy: Social theology and the views of Protestant clergy on social issues', Review of Religious Research 50(2), 221-240.

Hayes, J.H. \& Holladay, C.R., 1982, Biblical exegesis: A beginner's handbook, John Knox Press, Atlanta, GA

Kessler, J., 2013, Old Testament theology: Divine call and human response, Baylor University Press, Waco, TX.

Labahn, M., 2007, 'Deuteronomy in John's Gospel', in M.J.J. Menken \& S. Moyise (eds.), Deuteronomy in the New Testament, pp. 82-98, T. \& T. Clark, London.

Le Roux, J.H., 2005, 'Pro Pent: A project for the study of the Pentateuch in South Africa', in E. Otto \& J.H. le Roux (eds.), A critical study of the Pentateuch: An encounter between Europe and Africa, pp. 1-21, Lit Verlag, Münster.

Levin, C., 2014, 'Rereading Deuteronomy in the Persian and Hellenistic periods: The ethics of brotherhood and the care of the poor', in D.V. Edelman (ed.) Deuteronomy-Kings as emerging authoritative books: A conversation, pp. 48-71, Ancient Near East Monographs 6, Society of Biblical Literature, Atlanta, GA.

Levinson, B.M., 1997, Deuteronomy and the hermeneutics of legal innovation, Oxford University Press, New York.

Lim, T.H., 2007, 'Deuteronomy in the Judaism of the Second Temple period', in M.J.J. Menken \& S. Moyise (eds.), Deuteronomy in the New Testament, pp. 6-26, T. \& T. Clark, London.

Lohfink, N., 1996, 'The laws of Deuteronomy: A utopian project for a world without any poor', Scripture Bulletin 26, 2-19.

McConville, J.G., 1998, 'Deuteronomy', in G.J. Wenham, J.A. Motyer, D.A. Carson, and R.T. France (eds.), The New Bible Commentary, pp. 198-232, Inter-Varsity Press, Leicester.
McConville, J.G., 2002, Deuteronomy, Apollos Old Testament Commentary, Apollos, Leicester, England.

Mckeown, J., 2003, 'Land', in T.D. Alexander \& D.W. Bkaer (eds.), Dictionary of the Old Testament: Pentateuch, Inter-Varsity Press, Downers Grove, IL.

Mcllroy, D., 2011, 'The mission of justice', Transformation: An International Journa of Holistic Mission Studies 28(3), 182-194. https://doi.org/10.1177/0265378 811404789

Miller, P.D., 1990, Deuteronomy, John Knox, Westminster.

Mitchell, A.C., 1992, 'The social function of friendship in Acts 2:44-47 and 4:32-37', Journal of Biblical Literature 111(2), 255-272. https://doi.org/10.2307/3267543

Ndiyo, N.A., 2010, Poverty to sustainable development: A community-based approach, University of Calabar Press, Calabar.

Nelson, R.D., 2002, Deuteronomy: A commentary, Westminster John Knox Press, Louisville, KY.

Oosthuizen, M.J., 1997, 'Deuteronomy 15:1-18 from a socio-rhetorical perspective', Zeitschrift für Altorientalische und Biblische Rechtsgeschichte 3, 64-91.

Otto, E., 1994, Theologische Ethik des Alten Testaments, Kohlhammer, Stuttgart.

Pakkala, J., 2009, 'The date of the oldest edition of Deuteronomy', ZAW 121, 388-401. https://doi.org/10.1515/ZAW.2009.026

Routledge, R., 2008, Old Testament theology: A thematic approach, IVP Academic, Downers Grove, IL.

Rusam, D., 2007, 'Deuteronomy in Luke-Acts', in M.J.J. Menken \& S. Moyise (eds.), Deuteronomy in the New Testament, pp. 63-81, T. \& T. Clark, London.

Sacks, J., 2005. To heal a fractured world: The ethics of responsibility, Schocken Books, New York.

Scheffler, E., 2013, 'Of poverty prevention in the Pentateuch as a continuing contemporary challenge', Verbum et Ecclesia 34(2), Art. \#869, 1-14. https://doi. org/10.4102/ve.v34i2.869

Townsend, P., 2006, 'What is poverty? Concepts and measures', Poverty in Focus, December, pp. 5-6, viewed 29 August 2017, from http://www.ipc-undp.org/pub/ IPCPovertyInFocus9.pdf

Uhlenbruch, F., 2015, The nowhere Bible. Utopia, dystopia, science fiction, De Gruyter, Berlin.

Vogt, P.T., 2008, 'Social justice and the vision of Deuteronomy', Journal of Evangelical Theological Society 51(1), 35-44.

Von Rad, G., 1953, Studies in Deuteronomy, transl. D.M.G. Stalker, SBT 9, SCM, London.

Weinfeld, M., 1961, 'The origin of the humanism in Deuteronomy', Journal of Biblical Literature 80(3), 241-247. https://doi.org/10.2307/3264780

Weinfeld, M., 1991, Deuteronomy 1-11: A New Translation with Introduction and Commentary, AB 5, Doubleday, New York.

Wright, G.E., 1953, 'Deuteronomy', in G.A. Buttrick (ed.), The interpreter's Bible, pp. 311-330, Abingdon, Nashville, TN.

Wright, J.H., 1996, Deuteronomy, NIBC, Hendrickson, Peabody, MA

Wright, C.J.H., 2004, Old Testament ethics for the people of God, Inter-Varsity Press, Nottingham. 